\title{
Editorial
}

\section{Fifty Years On}

\author{
Giovanni A. Fava \\ University of Bologna, Department of Psychology, Bologna, Italy
}

Psychotherapy and Psychosomatics started in 1953 as Acta Psychotherapeutica, Psychosomatica et Orthopaedagogica. The editors (E. Carp and B. Stokvis) announced, in the first issue, the publication of a journal in the field of psychotherapeutics for studying 'fundamental problems in a field in which the consideration of man as a unit must form the basis of every form of psychotherapeutic endeavour'. Anticipating the developments of positive psychology, they viewed psychotherapy essentially as 'a form of re-education of the individual' by removing obstacles which prevent the full development of the individual. In 1960, the journal became Acta Psychotherapeutica et Psy- chosomatica, increasing the psychosomatic emphasis. In 1967, it changed to Psychotherapy and Psychosomatics, under the editorship of J. Ruesch, A.H. Schmale and T. Spoerri. It published articles in English, French and German. In 1975, Peter E. Sifneos became the editor, a position which he kept for two decades. The language of the journal then became English only. The blending of psychotherapy and psychosomatic research disclosed more and more its timeliness, particularly when, in the nineties, psychiatry shifted from 'brainless' to 'mindless'. We owe to these psychosomatic pioneers and clinicians the current developments of the journal, whose growth is exem-

Fig. 1. Impact factor of Psychotherapy and

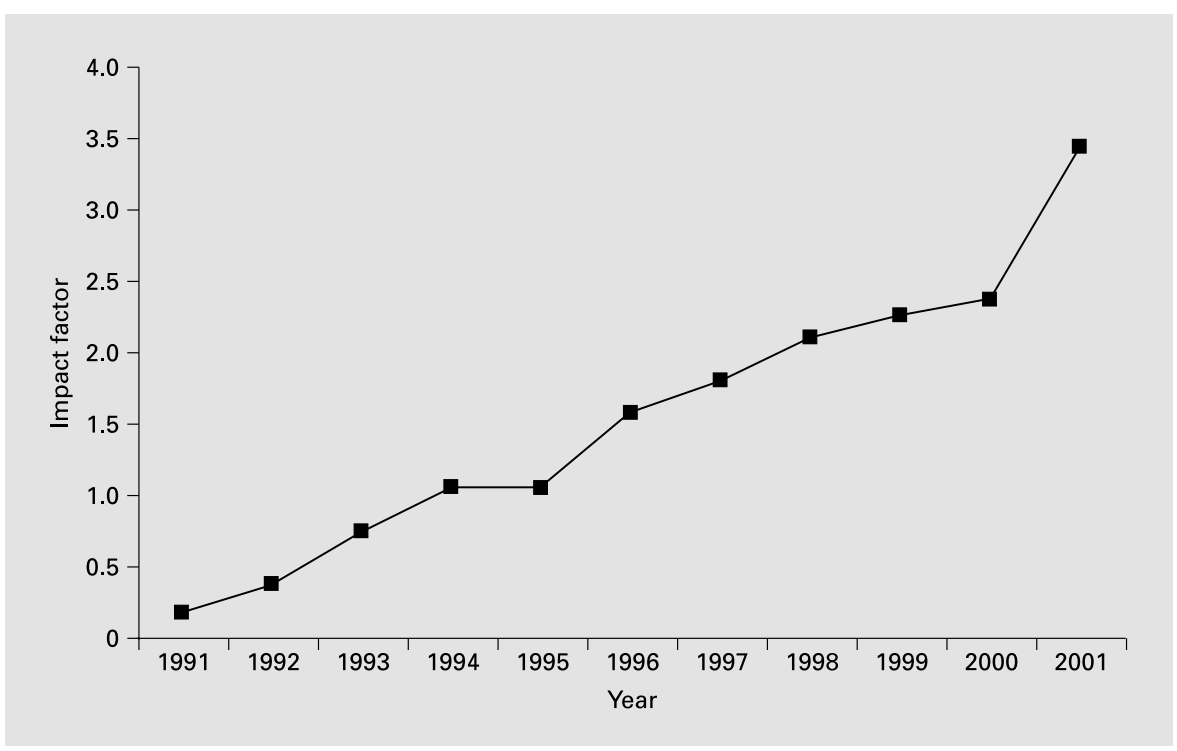
Psychosomatics in the last decade.

\section{KARGER}

Fax + 41613061234 E-Mail karger@karger.ch www.karger.com
(C) 2003 S. Karger AG, Basel

0033-3190/03/0721-0001\$19.50/0

Accessible online at: www. karger.com/pps
Prof. Giovanni A. Fava

Dipartimento di Psicologia

Università degli Studi di Bologna

Viale Berti Pichat, 5, I-40127 Bologna (Italy)

Tel. +39051243 200, Fax +39 051243 086, E-Mail fava@psibo.unibo.it 
plified by its impact factor (fig. 1). With an impact factor of 3.43 in 2001, the journal ranks 13th in the psychiatry listing (second of the European journals) and 5th in the psychology listing (first of the journals which publish original investigations) in the ISI Journal Citation Reports. It is now the top journal for psychotherapy and psychosomatic research. This year, the journal introduces a new section (case management), which addresses clinical issues that are seldom addressed in medical journals. Con- tributions are welcome. An important feature is that researchers with a substantial conflict of interest are excluded from this section.

As a result, Psychotherapy and Psychosomatics enters its fiftieth year alive, independent and fighting.

The contribution of the editorial board and of the following reviewers in the course of 2002 for achieving this goal is gratefully acknowledged.
Ananth J. (Los Angeles, Calif., USA)

Antonuccio D. (Reno, Nev., USA)

Battaglia M. (Milano, Italy)

Belaise C. (Modena, Italy)

Benazzi F. (Bologna, Italy)

Berenbaum I.T. (Champaign, Ill., USA)

Blanch J. (Barcelona, Spain)

Bouvard M. (Lyon, France)

Bouman T. (Groningen, The Netherlands)

Buddeberg-Fischer B. (Zurich, Switzerland)

Büchi S. (Zurich, Switzerland)

Cahill S. (Philadelphia, Pa., USA)

Coelho R.C. (Porto, Portugal)

De Girolamo G. (Bologna, Italy)

Delle Chiaie R. (Roma, Italy)

Fabbri S. (Bologna, Italy)

Facchinetti F. (Modena, Italy)

Faravelli C. (Firenze, Italy)

Fassino S. (Torino, Italy)

Favaro A. (Padova, Italy)

Grabe H.J. (Stralsund, Germany)

Grassi L. (Ferrara, Italy)

Grigioni F. (Bologna, Italy)

Healy D. (Bangor, UK)

Herrmann-Linger C. (Berlin, Germany)
Høglend P. (Oslo, Norway)

Honkalampi K.C. (Kirsu, Finland)

Hoyer J. (Dresden, Germany)

Iosifescu D.V. (Boston, Mass., USA)

Jaeger B. (Hannover, Germany)

Jorgensen R.S. (Syracuse, N.Y., USA)

Kronke K. (Indianapolis, Ill., USA)

Lam D. (London, UK)

Lazaratou H. (Athens, Greece)

Levenstein S. (Roma, Italy)

Lilienfeld (Atlanta, Ga., USA)

Littman A. (Boston, Mass., USA)

Majani G. (Pavia, Italy)

Mangelli L. (Bologna, Italy)

Mangweth B. (Innsbruck, Austria)

Mansueto C. (Silver Springs, Md., USA)

Mataix-Cols D. (London, UK)

Maule S. (Torino, Italy)

Mc Nally R. (Boston, Mass., USA)

Meyer T. (Berlin, Germany)

Moene F.C. (Dordrecht, The Netherlands)

Monteleone P. (Napoli, Italy)

Mota Cardoso R. (Porto, Portugal)

Ottolini F. (Modena, Italy)

Pariante C. (London, UK)
Pasquini P. (Roma, Italy)

Perlis R.H. (Boston, Mass., USA)

Petersen T.J. (Boston, Mass., USA)

Pope H.G. (Belmont, Mass., USA)

Porcelli P. (Bari, Italy)

Rafanelli C. (Bologna, Italy)

Ricca V. (Firenze, Italy)

Roncuzzi R. (Bologna, Italy)

Ruggeri M. (Verona, Italy)

Ruini C. (Bologna, Italy)

Russell J.M. (Dallas, Tex., USA)

Salmaso L. (Padova, Italy)

Schoenfeld R. (Goteborg, Sweden)

Scott J. (London, UK)

Simpson G.M. (Los Angeles, Calif., USA)

Singer B. (Princeton, N.J., USA)

Snaith P. (Leeds, UK)

Söndergaard H.P. (Stockholm, Sweden)

Sonino N. (Padova, Italy)

Sorensen B. (Odense, Denmark)

Stein D. (Tel-Hashomer, Israel)

Tansella M. (Verona, Italy)

Zachariae R. (Aarhus, Denmark)

Zimmermann C. (Verona, Italy) 